\title{
HET GOUDEN JUBILEUM VAN DE WEST INDIA COM- MITTEE CIRCULAR
}

DOOR

FRED. OUDSCHANS DENTZ

Het op 21 Mei 1936 verschenen nummer van de West India Com mittee Circular no 982 is een jubileumnummer. Immers het eerste nummer van dit tijdschrift verscheen een halve eeuw geleden. De vereeniging zelve, die het uitgeeft, is heel wat ouder; zij werd omstreeks 1750 opgericht (de juiste datum is, ondanks nauwkeurige nasporingen, niet kunnen worden vastgesteld). In $1904 \mathrm{kreeg}$ zij de Koninklijke goedkeuring van koning Edward VII. Onder den voorzitter Mr. (later Sir) Nevile Lubbock werd in de vergadering van 11 Mei 1886 tot de uitgave van een periodiek besloten, en het eerste nummer van de Circular in Mei 1886 besloeg slechts vier bladzijden. Dat was in een jaar van groote opleving der belangstelling in koloniale aangelegenheden. In dat jaar opende koningin Victoria te Londen de Koloniale en Indische tentoonstelling, waarvoor Tennyson de bekende, dikwijls aangehaalde, woorden schreef "One life, one flag, one fleet, one Throne". Van een maandelijksche uitgave werd de Circular in Augustus 1903 een veertiendaagsch orgaan in zijn huidigen omvang, veelal met fraaie afbeeldingen verlucht.

De President, Viscount Elibank, en de voorzitter, Sir Elliot de Pass, openen het jubileumnummer met een gelukwensch, welke gevolgd wordt door brieven van gelukwenschen van den toenmaligen minister van Koloniën Thomas en van de gouverneurs van Barbados, Britsch Guyana, Jamaïca, Trinidad, Leeward- en Windward-eilanden en Britsch Honduras. Het ledental van de vereeniging, waarvan Sir Algernon Aspinall, de schrijver van talrijke werken over West-Indië (wij herinneren alleen maar aan de Pocket Guide), secretaris is, ging wel door den druk der tijden van 2354 in 1927 achteruit, maar bedraagt toch nog 2062.

Als steeds bevat het tijdschrift een schat van wetenswaardig- 
194 GOUDEN JUBILEUM VAN DE WEST INDIA COMMITTEE CIRCULAR

heden. Geen wonder, de talrijke Britsche koloniën in de West leveren daarvoor ruim stof op. Een der afbeeldingen in dit nummer is de vergaderzaal met uitgebreide boekerij te Londen, 14 Trinity Square. Wij bieden de vereeniging en de redactie van de Circular ook onze gelukwenschen aan. 